\title{
Exploring Bicultural Ambivalence in Jhumpa Lahiri's The Namesake: Representational Diasporic Identities in Indian Anglophone Fiction
}

\author{
Hassan Bin Zubair ${ }^{1} \&$ Nighat Ahmed ${ }^{2}$ \\ ${ }^{1} \mathrm{PhD}$ Scholar (English Literature), National University of Modern Languages, Islamabad, Pakistan \\ ${ }^{2}$ Assistant Professor of English, National University of Modern Languages, Islamabad, Pakistan \\ Correspondence: Hassan Bin Zubair, National University of Modern Languages, Islamabad, Pakistan. E-mail: \\ hbz786@gmail.com
}

Received: April 14, 2018 Accepted: June 11, 2018 Online Published: July 28, 2018

doi:10.5539/ijel.v8n6p98 URL: https://doi.org/10.5539/ijel.v8n6p98

\begin{abstract}
This paper explores the cultural ambivalence and bicultural identity issues in Jhumpa Lahiri's The Namesake. This Indian Anglophone novel carries different diasporic sensibilities. Issues of marriage and culture are very prominent with the importance of family relationships in the context of immigrant feelings and loss of identity. Unconditional love and acceptance of family relations emerge victorious at the end of the narrative. The writer shares the second generation migrant experience since they were born to parents who immigrated and settled to United States. While migrants from some of the Asian states, mainly those characterized by most recent immigrant waves, have really worse socio-economic situation than average immigrants; Indians people are rather prosperous minorities. Theories presented by Bhabha, Clifford and Appadurai about culture and diaspora support this research. Lahiri do not portray immigrants' lives as a struggle to survive but rather concentrate on their affiliation to the country into which they arrived and also on their relationship with their American-born children. This research is helpful to know about the concerns associated with the liminal space and issues related to identity loss of first and second generations and living with a bicultural identity.
\end{abstract}

Keywords: diaspora, culture, marriage, anxiety, Indian, identity

\section{Introduction}

This research article is based on my unpublished doctoral thesis of English, in which I have tried to explore the bicultural ambivalence and issues related to Identity, economy, culture, marriage, religion and ideology in Indian and Pakistani diasporic Anglophone fiction. This specific research article also explores the issues of marriage, religion, identity and bicultural ambivalence in Jhumpa Lahiri's The Namesake with special physiognomies of Indian diasporic Anglophone fiction. The world at present has transformed to the status of "Global Village". This identity as the Global Village has brought the world into new horizons, issues, concerns, aspirations etc. The cross-cultural interaction and migratory movements are the issues prominently attached and interlinked with the cultural, social, psychological, gender-related, economic, political and geographical concerns. The cross-cultural migration has been continued for centuries and it has increased during the previous couple of decades. It has resulted in emergence of problems related with identity awareness and aspects of assimilation. Thus, the people in migration face various problems with the people and the land they visit, which results in the sufferings in their life. It has been a need of time to increase awareness in young generation about the possibilities of and the problems emerging in the cross-cultural migration because migrated people belong to a particular cultural background. The literature by the diasporic writers is a type of self-analysis, a sort of therapy for survival in this Darwinian global village, in which surrounding forces determine the creative output. The predicament and problems of women due to cross-cultural encounters in immigration have remained an issue of discussion for the South Asian Diasporic Anglophone writers. The number of cross-cultural marriages and immigrations are increasing day by day due to many reasons like advancement in Information Technology which mingles the world together.

The twenty-first century educated young generation must be acquainted with the possibilities and problems of cross-cultural marriages and immigrations, particularly sensational and emotional untrained youth. At present times, people of one country are migrating to other countries in search of betterment. Migration causes many troubles in the life of people. The diasporic literature functions as a tool to discuss the predicament and problems 
of people due to cross-cultural encounters in migration. Indian Writing in English is believed to be the production out of the cultural amalgamations which the Indian English novel expresses through all the phases of imitation, assimilation and self-expression. Indian Anglophone fiction continues to evoke colonial legacies in the contemporary society and seeks to compete with other literatures in English. The cultural point of view is helpful for analysis of the conditions that affect the significance of literature. The issues related to diaspora and cultures presented in the selected novel need to be discussed in details.

\subsection{Usage of Anglophone Language in Indian Diasporic Fiction}

The term 'Diaspora' has wide ranging connotations and complexities, and is very difficult to explain or define easily. Before proceeding, it is necessary to define and understand the term "Diaspora". The word Diaspora is associated and derived from the Greek words " scatter'. The Dictionary of Webster refers it as 'dispersion'; thus it includes a concept of a center or a "home". The Oxford Advanced Lerner's Dictionary also defines Diaspora as:

"The process by which people of a particular nation become

scattered and settle in another countries, especially Jews

who left ancient Palestine in this way." (Hornby, 1999)

Along with religious, philosophical, political and eschatological connotations the term 'Diaspora' refers to a special relationship between the native land and the people themselves. As the above definitions refer to the Jewish scattering, the term is essentially associated with the images of journey, voyage, displacement, seeking roots and settling feet on the alternative lands. The term is applicable to the migratory movement of Parsi community after the invasion of Persia by the Arab conquerors and the persecution of Parsis at their hands. Near about twelve hundred years ago they landed in India at Diu, off the coast of Gujarat in India to make this their alternative home. After settling down, they started a new life and while accepting a few conditions by the local leaders, they succeeded in keeping their own religion in a new country. In the same way the term is usable for the migratory movement of people after gruesome act of partition between India and Pakistan. The troubles, pains, losses, agonies and suffering quite distinguish them from others, as that had reached to the naked parade of women; but their quest for identity is akin to other immigrants. Like these two examples, the migration can take place out of force like economic, social, political or religious, and also out of choice and freewill as today people voluntarily leave their own country for higher education, better opportunities or better life. The term may also be applied to these people willingly migrating to other Western countries, which are promising greater economic benefits, pursuit of higher studies or cross-cultural marriages.

\subsection{Indian Diaspora and Anglophone Fiction}

Historically Indians are spurning isolation, but have been going to different parts of the world as traders, teachers, preachers, adventurers and soldiers. In ancient times Mesopotamia Meluhha and Dilmun bear witness to the outgoing and enterprising spirit of Harappan and Indus businessmen of the third millennium B.C. Since then with the vibrant links to the rest of the world, Indian civilization is celebrating its limitless capacity for accommodation, assimilation, readjustments and restatements. Indians sought and strive to disseminate Indian spiritual, intellectual and aesthetic ideas through diffusion of Hindu-Buddhist philosophies, art and agricultural traditions which influences the lives of a vast segment of humanity by providing a corrective alternative to many in the West disillusioned or disenchanted with their own heritage.

Later, in the face of sustained Muslim onslaughts, defeated and dejected Indians turned to their Gods for redemption. The purveyors of false purity prohibited travels to the foreign lands and islands; and the instruments of ostracism punished who dared to oppose the self-appointed custodians of the Hindu religion. When the Mughal Empire tottered and disintegrated, India succumbed to the imperial domination of the Britain, which dragged India against its will into the world around. The old taboos against foreign travel became ineffective and inoperative in the face of stark economic and political compulsions. The British industrial revolution and colonialism in Africa, Asia, the South Pacific and Caribbean needed cheap labor and India was inexhaustible reservoir of expendable indentured and voluntary labor. Out of the Indian diaspora to different parts of the British Empire a large number of indentured laborers sought salvation from penury and privation in the far-flung lands out of their free will and volition. The painful legacy of partition in 1947 and its later effects caused the Indian diaspora to continue still unabated, including skilled workers, businessmen, professionals, scientists and men and women of letters.

Later wave of migration consists of the professionals and the educated elite of India seeking economic betterment in the advanced countries where they are referred as 'model minority'. In the last decades of the 
twentieth century Indian talent has become a major source of knowledge for the technology-based economies of the First World countries. This 'model minority' has made Indian diaspora one of the most powerful Diasporas in the world. Ramesh Chandha points out:

"Owing to the close intercultural contact imposed on India by

Great Britain, the British and the Indian writers have produced

a considerable body of fiction that explores the seemingly

infinite subject of cultural interaction, commonly known as the

East-West dichotomy." (Chandha, 1988)

In spite of some impediments and atrocities, the Indian diaspora has the achievements, educational advancement, economic progress and political success. This story of the diaspora has provided material and scope for the diasporic writers to illustrate their history and heritage, their own awareness of their society and its problems, its achievements and its limitations and frustrations. A few have turned their attention to India to assess and explore their relationship with it by focusing on how they differ and diverge from many of the characteristics of Indian society. One may strongly agree with Dr. Annie John, who examines the case of writer of Indian diaspora as:

"The writers of Indian Diaspora have been aiming at re-inventing

India through the rhythms of ancient legends, the cadences of

mythology, the complexities of another civilization, cultural

assimilation and nostalgia." (John, 2012)

Their connection with India affects their perceptions. Thus, some of them disown the India, some grudgingly, sometimes reluctantly, sometimes apologetically own it, while others proudly uphold and applaud it through their writings. The present study specifically considers the written text in English by the Indian diasporic writer. Moreover, the juxtaposition of the contemporary happenings and developments in the diasporic Indian English novel may help to understand its nature, scope, newness and differences.

\section{Literature Review}

Vijay Mishra in his monumental work "Literature of the Indian Diaspora: Theorizing the Diasporic Imaginary" discusses in detail the works by renowned Indian Diaspora writers like Salman Rushdie, V.S.Naipaul, Bharti Mukharjee, Rohinton Mistry, M.G.Vassanji and Hanif Kureishi. He makes a distinctioin between old Indian Diaspora and their reasons after leaving the country as well as new Indian Diaspora subject and their reasons for preferring to settle in other land. Mishra in this book emphasizes the importance of understanding the history and background of a writer if one is to relish the book produced by that writer. Mishra discusses almost all the important texts by Naipaul and Rushdie and tries to state how Diasporic experiences shape their imagination and plots. He observes:

"They are precariously lodged within an episteme of real or imagined

displacements, self-imposed sense of exile; they are haunted by

specters, by ghosts arising from within that encourage irredentist or

separatist movements." (Mishra, 2007)

This book studies that how Indian writers writing in English have attempted all major literary genres and how fiction and poetry have dominated the Indian scenario.

Malti Agrawal rightly supports in the Editorial 'Section of this book the urge of the writers for writing in their mother tongues. Most of these Indian writers are bilinguals and are sometimes nostalgic for their mother tongue. Their contribution in Indianizing the English language is commendable. These writers have at times used native idioms and also words from their own vernacular to capture the true picture of the Indian society. These research papers touch the most sensitive issues such as social dichotomy, cultural hegemony, clash between ethnic groups, and conflict between eastern and western ideologies. Some of the papers of the book study in depth the poem of Kamala Das who is chiefly known for raising a voice of protest against exploitation of women. The book brings in limelight the voices raised by Indian women writers writing in English against gender bias and male chauvinism. This edited volume is of great help to the students and researchers who want to take a deep plunge into the ocean of Indian English Writing. Though the book is of great help, it does not include the critique of great writers from Indian regional languages. 
Jasbir Jain in "Writers of the Indian Diaspora" presents essays on diasporic writings which raise questions regarding the definitions of home and nation. Both the Indian and foreign contributors represent their perspectives located in different cultures. Ashish Gupta and Uma Parameshwaran write from their personal experiences of migration. Gurbhagat Singh explores the theoretical formulation. David Stouck's is mostly concerned with reading and reception theories. The writers like Shyam Asani, P.A.Abraham, Rajul Bhargav, B.R.Nagpal and Jasbir Jain develop their arguments through comparative perspectives. The volume presents a new paradigm to postcolonial evaluations and critiquing of diasporic writing.

\section{Aims and Objectives}

The present research aims at identifying the problems and its causes emerged due to the cross-cultural immigration and diasporic sensibilities. The causes and effects of their sufferings are to be discussed from the cultural points of view to reach to a certain conclusion. The present research has an objective of evaluating the life and problems of immigrant protagonist in the selected text. Another objective of the present research is to observe and analyze the facts related to the problems of immigrant women and youth in the selected text.

\subsection{Statement of the Problem}

This research paper addresses the issues of diaspora, cultural ambivalence and bicultural identity in Indian Anglophone fiction. Selected novel The Namesake by Jhumpa Lahiri is under research as it clearly highlights the cultural issues and problems of first and second generation immigrants. It also covers the concerns of broader area of hybridity.

\subsection{Scope and Limitations}

- The present research is limited to The Namesake by the diasporic Indian Anglophone writer Jhumpa Lahiri.

- Diasporic writers have written essays, poems, autobiographies, plays, travelogues, novels and short stories in English. Of these categories, a novel by Jhumpa Lahiri is selected, as she has presented the problems of diaspora with different cultural properties.

- This particular research focuses on diasporic, marital and cultural points which are determined to study the cross-cultural encounters.

\section{Research Questions}

Q.1: How have the issues of marriage and culture been highlighted in Indian diasporic Anglophone fiction?

Q.2: How has Jhumpa Lahiri projected the diasporic cultural ambivalence in the novel The Namesake?

Q.3: How have the problems related to first and second generations been brought to light while living in the liminal space?

\section{Theoretical Framework}

This research is qualitative in nature, theories presented by Homi K. Bhabha, James Clifford and Arjun Appadurai about culture and diaspora support this research as a theoretical framework. Lahiri do not portray immigrants' lives as a struggle to survive but rather concentrate on their affiliation to the country into which they arrived and also on their relationship with their American-born children. This research is helpful to know about the concerns associated with the liminal space and issues related to identity loss of first and second generations and living with a bicultural identity. James Clifford has selected for the major theorist, he has presented the best kind of details about diasporic physiognomies and his article "Diasporas" covers the real soul of this research. Bhabha's The Location of Culture, is selected for this research because it covers the cultural attributes with ideological basis. Arjun Appadurai's "Disjuncture and Difference in the Global Cultural Economy" provides the solid grounds to explore the cultural differences and bicultural ambivalence in global scenario.

\section{Analysis and Discussion}

Lahiri is considered as reflecting improved conditions of diasporic immigrants even more. Her characters are no longer contrastive to other Americans and they live in "the milieu in which brown skin matters exponentially less than a degree from Brown" (Waldman, 2008). It is therefore not only their parents' culture but also the era which shaped their literary concerns.

Lahiri's foreign family background is another important feature of her "overnight" literary fame. She was the author of first books which granted her the literary celebrity status. Before her first novel, Jhumpa Lahiri was completely unknown to the literary world. This paper, however, concentrates on Lahiri's first novel, The Namesake. The novel portrays the lives of the Ganguli family but it mainly concentrates on the life of Gogol Ganguli. The novel opens with the main character's mother, Ashima, giving birth in American hospital. The 
story then depicts the life of the protagonist's father's accident and his arranged marriage to Ashima. Mishra characterizes the lives of the immigrant parents in the novel as an attempt to "preserve their 'home cultures', and on the other hand they [parents] also try and groom their children for the American way of life" (Mishra, 2006). Lahiri's ability to understand the immigrant experience may stem from the fact that she depicts the general experience of loneliness and abandonment. In the first chapter, when Ashima is lonely and feels alienated, Lahiri does not portray the differences through ethnic or religious rituals but through Ashima's inner life.

The Namesake is a story of the predicament of two generations of the immigrants. It portrays how in the immigration and collision of cultures struggle comes out for the motherhood. It explores various problems in the identity building for the first and the second generations of the immigrants. It's a story of Ashima Ganguli who arrives in Boston as a young bride after her arranged marriage and realizes how isolated she has become while preparing to deliver her first child in a hospital at Massachusetts. In fact, an Indian woman wishes the emotional support at least at the time of her first delivery. In America she feels nothing normal.

"She is terrified to raise a child in a country where she is

related to no one, where she knows so little, where life

seems so tentative and spare." (Lahiri, 06)

She misses her favorite Indian food during her pregnancy. She nostalgically tries to compensate for it on her own:

"Ashima has been consuming this concoction throughout

her pregnancy, a humble approximation of the snack

sold for pennies on Calcutta sidewalks and on railway

platforms throughout India, spilling from newspaper

cones." (Lahiri, 01)

At the beginning of the novel the issues of culture and identity are presented. Ashima does not use her husband Ashoke's name openly. According to the Bengali-Indian culture:

"It's not the type of thing Bengali wives do.....a husband's

name is something intimate and therefore unspoken,

cleverly patched over." (Lahiri, 02)

However, Ashoke after the name of his favorite famous Russian author names his son as 'Gogol'. This is the same Russian writer whose book saved him in the rail accident. In that accident many people died, but Ashoke survives and only his back breaks. The Bengali children are given two names according to their culture, a pet name for family use, the other used by the rest of people. So, Gogol's public name becomes 'Nikhil'. Ashima approves this name given after the same Russian favorite writer Nikolai Gogol. The America regulations compel the Indian immigrants to make the adjustments with their original culture. The letter symbolically represents the hanging and blank identity for the immigrants.

Lahiri, however, depicts also Indian traditions but those are the customs which she experienced. Her ethnic representation varies from Bengali traditions of naming to the descriptions of Indian ethnic dresses and food. The novel's plotlines begin when Gogol's intended pet name becomes his official name. Lahiri has a direct experience with the Bengali custom of giving a child two names. Officially named Nilanja Sudeshna, Lahiri chose to be known as Jhumpa, a name which was once only her pet name (Dhingra \& Cheung, 2012). Asian American is the umbrella term referring not only to people from East Asia but also to people from other parts of the East. Kim and Lewis note that despite having been labelled as a single category since 1976, Asians differ in "culture, language, and regency of immigration" (Kim \& Lewis, 1994). It is also important to note that Asian Americans do not always act as isolated individuals but on the contrary, they often maintain contacts either with each other or with the country where they or their families come from. Therefore the term diaspora is important in this context. Diaspora refers to a community living in the host country but having strong ties to the country of their or their families' origin. Diaspora does not denote the first generation of migrants exclusively. Indian diaspora in America constitutes another group which is usually perceived as homogenous ethnic category but which is composed of many diverse subgroups. In spite of that, they can, in some circumstances, function as a distinct ethnic category. John Fenton claims that

"Diasporic Indians have multiple identities, and on one occasion 
they can think of themselves as of Indians and in another

situation they can see themselves as part of specific linguistic

or religious groups" (Fenton, 1988).

The opening story of the novel should be nevertheless recognized as occurring in 1968, as the novel states. While arranged marriages are not uncommon even today, they have a decreasing tendency. An article from 1960s shows that in "Bengal arranged marriages existed as the main model not only in villages, but also in cities" (Klass, 1966). Lahiri, however, does not deliberately concentrate on the peculiarity of Indian culture but rather informs about less problematic customs of Bengali or Indian community. The narrative of the arranged marriage at the beginning of the story therefore does not function as a tool to show the contrasts between Indian and American culture but rather stays in the background of the story. Ashima is not represented as oppressed woman or as obeying daughter and her marriage is not depicted as forced. While still young, Ashima is neither depicted as a child bride. Lahiri therefore do not picture the arranged marriage as forced act. There is yet one more attribute of Lahiri's narrative in The Namesake and that is her personal experience with the cultural traditions she portrays. The theme of naming is recurring in the whole novel. In spite of disliking his real name at first, Gogol later in the novel changes his name to Nikhil, which his parents intended as his "good name". Originating in Bengali cultural practice of choosing two names - one for a private use within the family and the second for a public use, the idea in the novel has its roots in Lahiri's life. Lahiri has therefore not chosen to integrate such topic without having good knowledge of it. It results in her neutral position toward the practice. Whereas Gogol dislikes his official name and changes his pet name to his official name, he does not question the Bengali custom. On the contrary, the narrative of naming shows that being different does not mean to be isolated in the U.S. When young Gogol visits a graveyard with his classmates, the story at the beginning seems to demonstrate Gogol's difference. As Chakraborty argues, "This moment of cultural break eventually transitions into one of affiliation as Gogol finds other unusual names" (Chakraborty, 2014). Whole narrative of naming therefore does not draw on Gogol's difference, but rather shows that the U.S. is the world where being different does not mean to be excluded.

Gogol was raised to perceive Indian culture as something which is natural to him. Despite moving to Calcutta for eight months which occurs to Gogol like "moving there", he is not anxious about the Indian culture since he does not perceive it as antithetical to American. They are only his belongings which he misses. The Indian culture is represented as something peculiar in the novel; it is not Gogol who is of such an opinion. When the mother of his girlfriend considers the cultural practices of his parents as something odd, Gogol does not share her conviction. While feeling that "a line has been drawn" between him and her, Gogol thinks of the cultural practices such as the arranged marriage of his parents as of "something at once unthinkable and unremarkable" (Lahiri 138). Whereas at that stage of his life he considers arranged marriage as something he would not choose for himself, he does not think of it as of something strange, never considering arranged marriage or Indian culture as oppressive. Gogol therefore does not act as a representative of only one culture. While dating only American girlfriends, he later marries Moushumi, a Bengali American woman. Despite the fact he neither denounced nor aspired to the concept of arranged marriage, their relationship resembles such a cultural practice. Bhalla shows that

"Marrying Moushumi resembles an arranged marriage in

that their first meeting is initiated by their mothers and

they are also united by their shared experiences and

culture" (Bhalla, 2012).

The similarity is moreover evoked by the traditional Indian wedding comprising Hindu ceremony. However, by evoking the quasi-arranged marriage Lahiri is not saying that Gogol or Moushumi act as a successor of Indian traditional culture. Their relationship does actually the opposite. While showing that they do not oppose the traditional customs, it also demonstrates that the ethnic affiliation does not mean that being Bengali or Indian does necessarily unite them. It is however not to say that Gogol acts as a representative of the Indian culture only. He should be rather considered as capable of blending to two cultures at the same time. In his notion, the Indian and the American cultures are not so different as not to be compatible.

Lahiri is the second generation migrant, she employs in her writing the knowledge of being raised in two cultures. Therefore, it is her second generation immigrant status which enables her to encompass the experience of living as bicultural individuals. The bicultural identity is created by various actors. While the second generation immigrants are confronted with Western principles through their peers or media, their families and diaspora 
community create the conception of another culture. Nevertheless, not all second generation migrants have to cope with the bicultural conflict. The important factor is how an individual can handle two cultural influences. "Those children of immigrants who perceive the culture of their parents as similar to the mainstream culture usually do not experience the bicultural conflict" (Stroink \& Lalond, 2009). Such an approach is reflected in the writing of Jhumpa Lahiri. Since she does not describe the Indian diasporic community as different from American society, the second generation Indian Americans do not feel the need to compromise between the two cultures. Consequently, they do not feel the difference between them and their parents which would be based on the cultural differences. Lahiri portrays the quarrels between the parents and children as the universal story. When Ashima has problems with her daughter Sonia during her adolescence, their confrontations are narrated as generational conflicts. Their clash is represented by "Ashima crying, Sonia slamming doors" and revolves around the themes such as hair coloring or Sonia's desire to add piercing in her ear" (Lahiri, 107). Whereas the story resembles generational clash, it is not possible to decide whether the confrontation does not have the origins in the cultural differences.

As has already been mentioned, the children of immigrants adapt to the culture of their parents through the contacts with their family and their community. Notwithstanding the source of the foreign culture, the extended contact with the culture of their parents can help the children perceive it as unproblematic. The acquisition of the attributes and norms of a culture can however occur either through the exposure to diaspora or through the institutional education. Such a gradual acquisition of the characteristics of another culture is also called enculturation. Ethnographic research of the middle and the upper class Hindu Indians in United States reveals that it is very common for the Indian Hindu parents to raise their children in accordance with their beliefs. Aside from the quasi-formal education occurring during weekends, it is also Ashima who teaches her children about the Indian culture. When she is with Gogol, she therefore "sings him the Bengali songs her mother had sung to her" (Lahiri, 35) and "teaches him to memorize a four-line children's poem by Tagore, and the names of the deities adorning the ten handed goddess Durga" (Lahiri, 54). Lahiri therefore presents her immigrant characters as actively modeling their children according to their ideals. The process of enculturation is hence described as deliberate the Indian immigrants want their children to be shaped by similar influences which they themselves experienced in their childhood. Such a partial recreation of Indian world therefore bridges the two generations together.

Some critics consider Lahiri to be an accurate native informant, other perceive her as an author deploying Orientalizing strategies. The situation of their immigrant parents is, however, different. Coming from the culture which the West perceives as Oriental, the parents in the novel preserve some traditional ethnic characteristics which are easily recognizable. It is frequently the character's ethnic appearance or the traditional food which evoke the sense of a different culture. It is nonetheless important to explore the role such representations play. The author employs the images of ethnic dresses in order to manifest the background of parents. The Indian traditional dress, sari, is mentioned already on the first page of The Namesake. Sari is then referred to thirty-eight times, which means it is mentioned on average on every tenth page. However, the traditional dresses are not uncommon among the Indians and even among the Indian diaspora women. A distinction should therefore be drawn between the two types of portraying the foreign cultures. One writing strategy is to represent a culture by their commonplace habits and the other is to hyperbolize certain customs. The sari is therefore depicted as part of Ashima's habitual routine and is not used to differentiate her from the western population. It is not only the function of the sari as of the ethnic marker, but also the structure which negates the notion of orientalism. As part of the novel is narrated from Ashima's point of view, it stresses her mental state, not her differences. It is not only the presence of traditional clothes which is apparent in the opening of The Namesake. Ashima, who only recently came to the U.S., prepares an Indian snack. The description of food hence does not serve the Orientalizing purpose, but it rather serves as a trope symbolizing the memories of the homeland. As Lahiri draws on the stories of successful Indian immigrants in America, the immigrant story is in the novel The Namesake not pictured as a struggle to assimilate to a new culture but, on the contrary, Lahiri's migrants as well as their children are no more alien to American culture. They can rather be characterized by their "dual identity". As Natalie Friedman argues:

"Lahiri, dismantles the stereotype of brown skinned

immigrant families that are always outsiders to

American culture and recasts them as cosmopolites, members of a shifting network of global travelers

whose national loyalties are flexible" (Friedman, 2008). 
Being a migrant therefore does not mean that characters have to be isolated because of their different background While Lahiri uses the trope of the food to represent the feelings of loneliness which Ashima experiences during her first months in the U.S., the trope of broken English is not used. The only exception is the moment when Ashima is at hospital giving birth to her first child. When asked whether she hopes for a boy or a girl, she mistakenly says that it does not matter "as long as there are ten finger and ten toe" (Lahiri, 07). Indians coming to America are usually not portrayed as speaking broken English. Their speech, however, has another feature which is considered to be characteristic of Indian immigrants. Lahiri also makes use of her life experiences, but the way she deals with the authenticity varies. Aware of her limited experience with the Indian culture, Lahiri portrays cultural practices which Indian immigrants perform in the U.S. When she addresses life in India before the main protagonist was born, she avoids the description of the Indian culture.

\section{Findings}

This paper presents, how different factors encourage migration and how the characters negotiate various other agencies of disruption during their stay abroad. Lahiri uses family as a vital unit that undergoes transformation both during and after migration. The Ganguli family forges ties with fellow Bengalis when they first arrive in the US. The local Bengalis act as the support network to the Gangulis, especially Ashima who feels completely alienated and forlorn amidst the unknown surroundings of the host country. Their practicing together Bengali customs and rituals form a strong sense of relation among Ashoke, Ashima and the other Bengali migrant characters to the extent that the other Bengalis who are migrants themselves almost become an extended family to the Gangulis. The characters of Gogol and Ashima undergo a process of self-realization towards the end of the narrative. Gogol's discovery of the book of short stories gifted to him by his father, Ashima's decision to return to Calcutta and stay with her brother's family for six months somewhere highlights the importance of family relationships in the novel. The very fact that Ashima does not wish to permanently return to Calcutta suggests that she has developed ties with the host country a country that had seemed alien to her for so long. The formation of her ties, probably through her children Gogol and Sonia who are now settled in the US undermine the affirmation of family relationships by the novelist. Similarly her decision to stay part time in Calcutta with her brother's family suggests that she is not ready to forget her past and family back in Calcutta. She is willing to navigate the two countries and explore newer possibilities in her family space that now spans two countries. As discussed earlier, Jhumpa Lahiri, in her consistent use of the present tense verb, emphasizes an open-endedness in her narrative. This literary strategy of Lahiri shows her inclination to hint towards further possibilities in the context of re-creating family space for the characters. For Ashima, Sonia and Gogol, migration ultimately becomes empowering that shapes their individual characters in a positive way. Without becoming a prey to essentialist positions, The Namesake subverts attempts to frame a hegemonic condition of inscribing a singular identity on the structure of family. The Ganguli family thus restructures even at the end of the novel with Ashima shifting to her brother's place in Calcutta, Gogol, while living in the US, trying to trace his roots that have origins in India and Sonia marrying Ben, a half Chinese young man. All these characters' familial affiliations spread beyond political borders and boundaries.

Similarly Gogol's beginning to read the book of short stories gifted to him by his father eighteen years ago emphasizes the reaffirmation of the relation between father and son. The flood of memories that Gogol experiences when he sees his father's handwriting "rising gradually, optimistically, on the diagonal toward the upper right-hand corner of the page" (Lahiri, 2003), suggests a glimmer of hope in Gogol's personal life, scarred by a series of failures. The fact that Gogol is reminded of the pay-checks indicates the positioning of Ashoke as someone who had provided economic security to his family. Even after his death, Ashoke continues to provide emotional security to Gogol. Much like the overcoat of Nikolai Gogol's Akaky Akakievich, Ashoke provides the warmth and emotional security to Gogol even after his death. Lahiri does seem to say that it is family relationships that provide the necessary emotional stamina to characters stuck in the painful vortex of diaspora.

\section{Conclusion}

In her The Namesake, the Indian-American people struggle to create and nurture their identities in the new American landscape. Immigrants are projected outwardly as powerless in the Western society. Lahiri reveals her characters' inner adaptabilities. Ashima's cultural growth is intertwined with the growth of her children while educating them; she too gains a sort of education. Lahiri makes a decisive breakdown in the culture which turns out with the potential for pessimism. A pure cultural Bengali identity is irretrievably lost when the characters come to the United States. Ashoke's Bengali-American identity is lost along with his death. The next generation creates its own manifestation of the cross-cultural identity. Along with the strong cultural ties with mother, Lahiri also indicates the impossibility of a perfect union between the Indians and Americans. The breakdown in Gogol's marriage with Moushumi is a concrete example of the failure in an identity creation within the 
Bengali-American culture. In other words, in the generational growth immigrants lose their roots. The immigrants remain in a perpetual search for their own definition. The blending of Indian and American cultures manifests the different cultural identities warranting a new definition for the Indian-American immigrants. Ashima does not face the troubles of the Diaspora in its endurance of slavery and racial violence. In spite of this, her cultural essentialism is in vain. If a culture ever existed in its purest form, it cannot be saved. The white woman Mrs. Buxton at the library helps Ashima to gain career independence and to share her Bengalines with the American co-workers. This causes a real intercultural bonding that characterizes the international cooperation of women. The narrative implies that the cultural retention is important but with the revision of cultural elements, so that they remain useful and realistic. They are regretful for their cultural displacement due to the separation from their original cultures. The Indian food marks the cultural difference between Indian and American culture. The 'force' of relationships and religion seems doomed to failure because of the powerful 'sentiment' and tears of protest. While focusing on the marriage, Lahiri presents the disconnected feelings, the feelings of disorientation associated with the immigration and the cross-cultural differences.

\section{References}

Agrawal, M. (2007). New Perspectives on Indian English Writings. New Delhi: Atlantic Publishers and Distributors (P) Ltd.

Bhalla, T. (2012). Being (And Feeling) Gogol: Reading and Recognition in Jhumpa Lahiri's The Namesake. Melus, 1, 105-129. https://doi.org/10.1353/mel.2012.0013

Chadha, R. (1988). Cross-Cultural Interaction in Indian-English Fiction. New Delhi: National Book Organization (Publishers-Distributors).

Chakraborty, M. (2014). Adaptation and the Shifting Allegiances of the Indian Diaspora: Jhumpa Lahiri's and Mira Nair's The Namesake(s). Literature-Film Quarterly, 4, 609.

Dhingra, L., \& Cheung, F. (2012). Naming Jhumpa Lahiri: Canons and Controversies. Lanham: Lexington, Print.

Fenton, J. Y. (1988). Transplanting Religious Traditions: Asian Indians in America. New York: Praeger, Print.

Friedman, N. (2008). From Hybrids to Tourists: Children of Immigrants in Jhumpa Lahiri's: The Namesake. CRITIQUE: Studies in Contemporary Fiction, 1, 111. https://doi.org/10.3200/CRIT.50.1.111-128

Hornby, A. S. (1999). Oxford Advanced Learners' Dictionary (5th ed.). New York: Oxford University Press.

Jain, J. (2003). Writers of the Indian Diaspora. Jaipur: Rawat Publication.

John, A. (2012). In Search of Greener Pastures (Vol. 1). Mumbai: Pen Craft Publications.

Kim, P. S., \& Lewis, G. B. (1994). Asian Americans in the Public Service: Success, Diversity, and Discrimination. Public Administration Review, 54(3), 285-290. https://doi.org/10.2307/976733

Klass, M. (1966). Marriage Rules in Bengal. American Antropologist, 68(4), 951-979. https://doi.org/10.1525/aa.1966.68.4.02a00060

Lahiri, J. (2004). The Namesake. London: Harper Perennial, Print.

Mishra, S. (2006). The Identity Crisis-An Immigrant Experience as Reflected in Jhumpa Lahiri's Novel The Namesake. In B. Mishra \& S. Kumar (Eds.), Indian Writings in English. New Delhi: Atlantic and Distributors, Print.

Mishra, V. (2007). Literature of the Indian Diaspora: Theorizing the Diasporic Imaginary. London: Routledge.

Stroink, M. L., \& Lalonde, R. N. (2009). Bicultural Identity Conflict in Second- Generation Asian Canadians. Journal of Social Psychology: SPORTDiscus with Full Text.

Waldman, A. (2008). The Assimilation Artist. New Republic. N.p. Web. 29 Mar. 2015.

\section{Copyrights}

Copyright for this article is retained by the author, with first publication rights granted to the journal.

This is an open-access article distributed under the terms and conditions of the Creative Commons Attribution license (http://creativecommons.org/licenses/by/4.0/). 